\title{
Preschool Education in Turkey During the Covid-19 Pandemic: A Phenomenological Study
}

\author{
Bekir Yıldırım ${ }^{1}$ iD \\ Accepted: 6 January 2021 / Published online: 23 January 2021 \\ (c) The Author(s), under exclusive licence to Springer Nature B.V. part of Springer Nature 2021
}

\begin{abstract}
This study investigated the repercussions of the Covid-19 pandemic on preschool education and sought answers to how preschool education is implemented, what kind of activities are held, what kind of challenges need to be overcome, and what measures need to be taken to sustain preschool education. The sample consisted of 25 preschool teachers and 30 parents recruited using criterion sampling, a purposive sampling method. The study was based on phenomenology, which is a qualitative research design. Data were collected using a semi-structured interview form and video records of participants performing educational practice within two months. Data were analyzed using inductive content analysis. Participants stated that the Covid-19 pandemic had numerous adverse effects on preschool education and that they held art, science, and mathematics activities and games to sustain education but faced numerous challenges during the process. They also emphasized that measures should be taken to sustain preschool education during pandemics.
\end{abstract}

Keywords Covid-19 $\cdot$ Preschool $\cdot$ Preschool teacher $\cdot$ Parent $\cdot$ Phenomenology

\section{Introduction}

There have been several pandemics throughout history, such as smallpox, cholera, plague, and SARS. However, it is impossible to predict when and why a pandemic starts or reappears. Each century typically witnesses at least three outbreaks. For example, the Spanish flu, Asian flu, and Hong Kong flu were the pandemics of the twentieth century. In recent years, there have been six major epidemics, such as H5N1, H1N1, and Ebola (Gostin and Friedman 2015). Such pandemics affect human life in many aspects because some are extremely contagious and spread across countries and continents rapidly (Verikios et al. 2015). Infectious influenza affects societies in many aspects ranging from health to the economy (Davies 2013). For example, the Ebola outbreak caused high death rates in China and West Africa and affected basic areas, such as health, tourism, travel, and the economy (Nabarro and Wannous 2016). Education is one of those areas affected by outbreaks. Hundreds of millions of students worldwide have been affected by school

Bekir Yıldırım

bekir58bekir@gmail.com

1 Mathematics and Science Education, Mus Alparslan University, Mus, Turkey and university closures due to the Covid-19 outbreak. In some cases, school closures should occur immediately in an outbreak because students constantly contact each other, making the virus spread faster and increasing the death toll. For example, kindergartens, primary schools, secondary schools, high schools, and universities were closed during the $2009 \mathrm{H} 1 \mathrm{~N} 1$ pandemic to slow down the spread of the virus (Kawano and Kakehashi 2015). Different ways are being sought to continue education during outbreaks. Similar ways have been sought to continue education without interruption during the Covid-19 pandemic as well.

Digital learning has become the rule of the Covid-19 outbreak (Karp and McGowan 2020). Universities and schools reach their students through distance education programs and open education platforms to ensure that education continues without disruption (UNESCO 2020). During the Covid-19 outbreak, different digital learning platforms have gone mainstream and upended typical education practices and models. For example, primary school, secondary school, high school, and university level classes are broadcast by Education Information Network (EIN) TV channels (2020). However, EIN TV does not offer preschool education. Therefore, preschool teachers and parents have had to find other means and digital learning environments for that. Preschool education is interrupted 
during pandemics because there are no related programs and because such programs would have to be child-centered, not subject-centered (Turan 2004). Although some studies have investigated the effects of outbreaks on education (Burgess and Sievertsen 2020; Viner et al. 2020), there is no research on how to carry out preschool education during outbreaks, causing uncertainty for preschool teachers and parents. Therefore, more research should be conducted to guide preschool teachers and parents to collaborate to achieve sustainable preschool education during pandemics.

This study is critical because there is little published research examining the effects of the Covid-19 pandemic on preschool education (Massachusetts Office of the Child Advocate 2020; Pramling Samuelsson et al. 2020). Therefore, we believe that this study will pave the way for further research. This study also focused on the activities performed by preschool teachers and parents to sustain preschool education, as well as on the problems that they encountered and the solutions they offered during the Covid-19 pandemic. Therefore, the study focused on how preschool education is implemented, what kind of activities are held, what kind of challenges need to be overcome, and what measures need to be taken to sustain education. In this context, the main research question was, "What do preschool teachers and parents think are the repercussions of the Covid-19 pandemic on preschool education?" The study also sought answers to three subquestions to determine the effects of the Covid-19 pandemic on preschool education in line with the observations of teachers and parents. The three subquestions are as follows:

1. What effects do preschool teachers think the Covid-19 pandemic has on preschool education?

2. What effects do parents think the Covid-19 pandemic has on preschool education

3. What are the reflections of the Covid-19 pandemic on the education videos of preschool teachers and parents?

\section{Method}

\section{Design}

Phenomenology, a qualitative research design, was used to determine the effects of the Covid-19 pandemic objectively, validly, and reliably on preschool education. The objective of phenomenological research is to explain how people comprehend and make sense of their shared experiences with a phenomenon, concept, or event (Yıldırım and Şimşek 2011). This study aimed to analyze and interpret what preschool teachers and parents thought about the effects of the Covid19 pandemic on preschool education.

\section{Participants}

Participants were recruited using criterion sampling, which is a purposive sampling method. The main purpose of criterion sampling is to recruit a sample that satisfies a set of predetermined criteria (Yıldırım and Şimşek 2011). Criteria sampling is a time- and cost-efficient method by which researchers select participants most suited to the research purpose (Patton 2002). The inclusion criteria for preschool teachers were: (1) being voluntary participants, and (2) providing distance education. The inclusion criteria for parents were: (1) having a preschooler, (2) being in contact with preschool teachers and providing education to their children, and (3) being voluntary participants. The sample consisted of 25 preschool teachers $($ female $=22$, male $=3$ ) and 30 parents ( 26 female, 4 male). The preschool teachers had 1-25 years of work experience; three were pursuing a master's degree, while the remaining 22 had a bachelor's degree. Of the parents, two had a primary school degree, four had a secondary school degree, nine had a high school degree, two had an associate degree, 11 had a bachelor's degree, and two had a master's degree. Of the participant parents, 20 were homemakers, four were teachers, and six were involved in other occupations. They had an average monthly income of $\$ 950$, which is classified as "low income" $(<\$ 995)$ by the World Bank. Participants were assigned pseudonyms (Dilek, Ali, etc.) to ensure confidentiality and to protect their anonymity.

\section{Data Collection Tools}

\section{Covid-19 Interview Form}

Semi-structured interviews were conducted to determine what preschool teachers and parents think about the effects of the Covid-19 pandemic on preschool education. To that end, a Covid-19 Preschool teacher Interview Form (Cov19TIF) and a Covid-19 Parent Interview Form (Cov19PIF) were developed. The Cov19TIF form consisted of seven items while the Cov19PIF form consisted of six items. All items were easy-to-understand open-ended questions. Two experts in the field of preschool education were consulted. The forms were revised based on their feedback. A pilot study was conducted with two preschool teachers and two parents, and the forms were then finalized based on their feedback on clarity, wording, relevance, and comprehension (see Appendix "Preschool Teachers Interview Form (PTIF)"). 


\section{Videos}

Participants were asked to videotape their educational practices to support the interview outcomes. These videos were 5-15-min-long, and consisted of activity videos by preschool teachers, activity videos by parents, and videos made during distance learning. There were 50 videos in total.

\section{Data Analysis}

First, interviews and video-recordings were collected and transcribed. Second, codes were developed. Third, themes and categories were developed based on a literature review. Fourth, the themes, categories, and codes were tabulated and interpreted. Data were analyzed using inductive content analysis. Participants were interviewed, and then, the interviews were transcribed. Two experts developed themes, categories, and codes. They identified the parts on which they agreed and disagreed and discussed those parts to reach a consensus. Afterwards, interrater reliability was calculated using the formula [Reliability $=$ (number of agreements) / (number of agreements + number of disagreements)*100] (Miles and Huberman 1994). The interrater reliability in this study was $((240 / 240+32) * 100)=88.23 \%$, indicating acceptable reliability. Categories and themes were determined based on a literature review. The codes were assigned to those categories and themes. Afterwards, the data were analyzed using inductive analysis.

\section{Results}

Themes, categories, and codes were presented in tables related to the research questions. Direct quotations were used to provide an accurate and coherent picture of participants' views and to allow readers to easily analyze and interpret the findings.

\section{Preschool Teachers' Views of the Effects of the Covid-19 Pandemic on Preschool Education}

\section{The Effects of the Covid-19 Pandemic on Preschool Education}

The first research question of the first subproblem addressed preschool teachers' views of the effects of the Covid-19 pandemic on preschool education.

Most preschool teachers stated that the Covid-19 pandemic affected preschool education negatively in many aspects, whereas, some stated that it resulted in higher parental engagement in their children's education and an improvement in student-parent interaction (Table 1).
Activities for Sustainable Preschool Education

The second research question of the first subproblem addressed preschool teachers' views of activities for sustainable preschool education.

Preschool teachers stated that they provided distance education, designed and sent activities, and gave feedback about them to ensure sustainability in preschool education during the Covid-19 pandemic (Table 2).

\section{Preschool Education Activities During Covid-19 Pandemic}

The third research question of the first subproblem addressed preschool teachers' views of preschool education activities during the Covid-19 pandemic.

Preschool teachers stated that they performed art, Turkish, science, drama, music, and math activities and games during the Covid-19 pandemic (Table 3).

\section{Target Skills and Concepts}

The fourth research question of the first subproblem investigated what target skills preschool teachers helped their students to develop and what concepts they aimed to teach them.

Preschool teachers' views of target skills and concepts were grouped under two themes, eight categories, and nineteen codes. Preschool teachers stated that they would like to help their students develop the skills of collaboration, flexibility, and harmony, and how to turn abstract concepts into concrete forms, and to teach them the concepts of health-cleanliness-hygiene, numbers, shapes, and patterns (Table 4).

\section{Ways of Communication with Parents and Students During Covid-19 Pandemic}

The fifth research question investigated how preschool teachers communicated with parents and students during the Covid-19 pandemic.

Preschool teachers stated that they talked to parents and students mostly on (1) the phone and (2) WhatsApp, followed by (3) video-call, (4) Facebook, or (5) Instagram. The following are some related quotes from the participants:

Gözde: "I call the kids regularly and when they need me to."

Aydan: "I use WhatsApp because of socio-economic conditions. Participation is low anyway, so I have no problem talking to four students at the same time."

Ayça: "We already have some WhatsApp groups. I talk to them on WhatsApp, and I sometimes videocall them." 
Table 1 Preschool teachers' views of the effects of Covid-19 pandemic on preschool education $(n=25)$

\begin{tabular}{|c|c|c|}
\hline Theme & Category & Code \\
\hline $\begin{array}{l}\text { Effects of Covid-19 Pandemic on pre- } \\
\text { school education }\end{array}$ & Negative & Teaching basic concepts $(n=13)$ \\
\hline
\end{tabular}

Emotional development $(\mathrm{n}=11)$

Mental development $(n=10)$

Preschool teacher-student interaction $(n=6)$

Face to face education $(n=6)$

Preparation for primary school $(\mathrm{n}=5)$

Learning by doing $(\mathrm{n}=5)$

Social development $(n=4)$

School adaptation $(\mathrm{n}=3)$

Positive Parent-student interaction $(\mathrm{n}=7)$

Parental engagement $(n=6)$

\section{Quotations}

“We couldn't teach the basic concepts that we were supposed to because of the pandemic." Ahmet

"The pandemic has negatively affected students' emotional development." Dilek

"They used to enjoy coming to school, but now they have to stay away from it, which has negatively affected their attitudes towards it." Feyza

"Students have missed out on schooling during the pandemic, which has negatively affected their emotional development. They miss their schoolmates." Elif

"I think that the pandemic has negatively affected students' mental development." Hatice

"The cognitive development of the students has been interrupted because they didn't get to acquire the knowledge and skills that they were supposed to during this period. This has affected their thinking capacity." Zehra

"I think that the pandemic has negatively affected preschool teacher-student interaction." Ayça

"The students cannot interact with us, which negatively affects them."

"Face to face education is always effective in preschoolers, but we cannot do it because of the pandemic." Betül

"Face-to-face education is particularly important during the preschool period, and we see its benefits with our own eyes." Hatice

"The pandemic has negatively affected the preparation process for primary education." Buket

"Preschool education is based on learning by doing, but distance education wouldn't allow that." Büşra

"The pandemic has hindered the social interaction between students." Ali

"The students cannot interact, but instead, they have to use different electronic means of communication." Melike

"The pandemic has negatively affected school adaptation because there is no perception of school yet." Fatma

"The kids didn't have a chance to adapt to school and so couldn't develop a perception of it." Elif

"There has been an increase in studentparent interaction during the pandemic, and so, I guess this is one of the perks of the pandemic." Melike

"The pandemic has a positive consequence; there has been an increase in parents' engagement in their children's education." Aylin 
Table 2 Activities for sustainable preschool education $(n=25)$

\begin{tabular}{|c|c|c|}
\hline Theme & Code & Quotations \\
\hline \multirow[t]{7}{*}{ Sustainable Preschool education } & Distance education $(\mathrm{n}=25)$ & $\begin{array}{l}\text { "After getting permission from parents, I provide distance education } \\
\text { to put them at ease." Aydan } \\
\text { "I've been using distance education programs to reach the students } \\
\text { since the outbreak of the Covid-19 pandemic." Ali }\end{array}$ \\
\hline & Sending activities $(n=13)$ & $\begin{array}{l}\text { "I plan activities and send them to parents." Halime } \\
\text { "I plan simple activities and explain them clearly to parents on } \\
\text { WhatsApp." Aylin }\end{array}$ \\
\hline & Giving feedback $(\mathrm{n}=10)$ & "I ask for photos of activities every day and give feedback." Zehra \\
\hline & Keeping in touch with students $(\mathrm{n}=8)$ & $\begin{array}{l}\text { "During the pandemic, teachers should keep in touch with students." } \\
\text { Feyza } \\
\text { "I contact the students on WhatsApp three or four times a week." } \\
\text { Zehra }\end{array}$ \\
\hline & Sharing practice videos $(n=6)$ & $\begin{array}{l}\text { "I share videos for activities they can easily do with materials they } \\
\text { can easily get ahold of." Medine } \\
\text { "I send students videos of stories." Halime }\end{array}$ \\
\hline & Communicating with parents $(\mathrm{n}=5)$ & $\begin{array}{l}\text { "I contact parents to ensure sustainability and effectiveness in educa- } \\
\text { tion." Elif }\end{array}$ \\
\hline & Recommending books $(\mathrm{n}=2)$ & "I recommend books to students." Dilara \\
\hline
\end{tabular}

Table 3 Preschool education activities during Covid-19 pandemic $(\mathrm{n}=25)$

\begin{tabular}{lll}
\hline Theme & Category & Codes \\
\hline Preschool activities & Artistic activities $(\mathrm{n}=4)$ & Cutting $(\mathrm{n}=4)$ \\
& Tearing-Gluing $(\mathrm{n}=2)$ \\
& Coloring $(\mathrm{n}=2)$ \\
& Purkish activities & Poetry reading $(\mathrm{n}=1)$ \\
& Tongue twisters $(\mathrm{n}=1)$ \\
& Story-telling $(\mathrm{n}=1)$ \\
& Experimenting $(\mathrm{n}=4)$ \\
& Using simple tools $(\mathrm{n}=1)$ \\
& Food preparation in the kitchen $(\mathrm{n}=1)$ \\
Drama activities & Role-playing $(\mathrm{n}=1)$ \\
Music activities & Singing $(\mathrm{n}=2)$ \\
& Moving to music $(\mathrm{n}=1)$ \\
Math activities & Recognizing geometric shapes $(\mathrm{n}=2)$ \\
& Counting $(\mathrm{n}=1)$ \\
& Adding/subtracting $(\mathrm{n}=1)$ \\
Games & Pair games $(\mathrm{n}=2)$ \\
& Individual games $(\mathrm{n}=2)$ \\
&
\end{tabular}

\section{Challenges of Distance Education and Preschool Teachers' Recommendations}

The sixth research question of the first subproblem investigated the challenges preschool teachers faced and their recommendations for sustainable preschool education during the Covid-19 pandemic (Table 5).

The challenges of preschool education for preschool teachers during the Covid-19 pandemic were grouped under four categories and 15 codes. They stated that they had a hard time reaching all students and had to deal with Internet connection issues and reluctant parents.

Table 6 shows preschool teachers' recommendations for preschool education during the Covid-19 pandemic.

Preschool teachers' recommendations for preschool education during the Covid-19 pandemic were grouped under five categories and 12 codes. Their recommendations included informing parents about the pandemic, making the Internet stronger, and preparing a preschool education program (Table 6). 
Table 4 Target skills and concepts $(n=25)$

\begin{tabular}{|c|c|c|}
\hline Theme & Category & Code \\
\hline \multirow[t]{14}{*}{ Target skills } & \multirow[t]{4}{*}{ Learning and innovation skills } & Collaboration $(n=7)$ \\
\hline & & Problem-solving $(\mathrm{n}=3)$ \\
\hline & & Communication $(\mathrm{n}=2)$ \\
\hline & & Critical thinking $(\mathrm{n}=1)$ \\
\hline & \multirow[t]{3}{*}{ Life and career skills } & Flexibility and harmony $(n=6)$ \\
\hline & & Social and intercultural skills $(n=5)$ \\
\hline & & Responsibility $(\mathrm{n}=3)$ \\
\hline & Information, media, and technology skills & Technology literacy $(n=3)$ \\
\hline & \multirow[t]{3}{*}{ Ways to access information } & $\begin{array}{l}\text { Turning abstract concepts into } \\
\text { concrete forms }(n=6)\end{array}$ \\
\hline & & Active engagement $(n=6)$ \\
\hline & & Observation $(\mathrm{n}=1)$ \\
\hline & Mental skills & Hand-eye coordination $(n=3)$ \\
\hline & \multirow[t]{2}{*}{ Emotional skills } & Awareness $(n=5)$ \\
\hline & & Self-confidence $(n=2)$ \\
\hline \multirow[t]{5}{*}{ Target concepts } & \multirow[t]{2}{*}{ Life science } & Health-cleanliness-hygiene $(n=14)$ \\
\hline & & Hand-washing $(\mathrm{n}=10)$ \\
\hline & \multirow[t]{3}{*}{ Math } & Numbers $(n=3)$ \\
\hline & & Shapes $(n=2)$ \\
\hline & & Patterns $(n=1)$ \\
\hline
\end{tabular}

\section{Measures for Sustainable Preschool Education During Outbreaks}

The seventh research question of the first subproblem addressed preschool teachers' views of measures that should be taken for sustainable preschool education during outbreaks.

Some of the measures that preschool teachers think should be taken for sustainable preschool education during outbreaks were preparing preschool activity videos, providing Free Internet access, starting a TV channel for preschool education, and providing in-service training to preschool teachers (Table 7).

\section{Parents' Views of Effects of Covid-19 Pandemic on Preschool Education}

\section{The Effects of the Covid-19 Pandemic on Preschool Education}

The first research question of the second subproblem addressed parents' views of the effects of the Covid-19 pandemic on preschool education.

Almost all parents stated that the Covid-19 pandemic had numerous negative effects on preschool education, while only one parent stated that it resulted in increased parentstudent interaction (Table 8).

\section{Home Preschool Education Activities During COVID-19 Pandemic}

The second research question of the second subproblem addressed parents' views of home preschool education activities during the Covid-19 pandemic.

While most parents stated that they performed activities only sent by preschool teachers, the remaining stated that they performed not only the activities sent by preschool teachers, but also other supportive activities during the Covid-19 pandemic (Table 9).

\section{Challenges of Preschool Education for Parents During Covid-19 Pandemic}

The third research question of the second subproblem addressed the challenges of preschool education for parents during the Covid-19 pandemic.

Parents stated that they encountered various challenges during preschool education during the Covid-19 pandemic. Their views were grouped under four categories and eleven codes (Table 10).

Parents made various recommendations for preschool education during the Covid-19 pandemic. Their recommendations were grouped under three themes and eight codes (Table 11) 
Table 5 Challenges of preschool education for preschool teachers during Covid-19 pandemic $(n=25)$

\begin{tabular}{ll}
\hline Theme & Category \\
\hline $\begin{array}{l}\text { Challenges of Preschool education } \\
\text { for Preschool Teachers }\end{array}$ & $\begin{array}{c}\text { Of environment and situation } \\
\text { origin }\end{array}$
\end{tabular}

for Preschool Teachers

origin
Lack of materials $(n=2)$

Of parent origin

Of student origin

Of preschool teacher origin
Lack of sources $(n=2)$

\section{Code}

Failure to reach students $(\mathrm{n}=25)$

Financial difficulties $(n=4)$

Reluctant parents $(n=5)$

Failure to reach parents $(n=4)$

Parental intervention in education $(\mathrm{n}=4)$

Parents not giving feedback $(\mathrm{n}=3)$

Lack of concentration $(n=7)$

Students speaking at the same time $(\mathrm{n}=3)$

Failure to perform activities $(\mathrm{n}=2)$

Inappropriate for student level $(\mathrm{n}=1)$

Lack of knowledge $(\mathrm{n}=3)$
Quotations

“We can't reach all students during this period, so some of them lag behind." Dilara

"We have to deal with Internet connection issues." Betül

"Low-income parents do not have access to the Internet." Ayça

"Parents don't have enough internet connectivity, which is another problem." Esin

"Parents do not have the materials necessary for activities available at home." Buket

"Parents don't have the materials to perform the activities." Esra

"There are not enough resources for preschool education." Büşra

"Parents are reluctant about distance education, which makes it more challenging." Dilek

"Some parents do not want to communicate." Fatma

"We have a hard time involving parents and communicating with them." Feyza

"Parents stick their noses into their kids' education, which is a nuisance." Melike

"Parents wouldn't give feedback on activities." Aylin

"I can't evaluate the process adequately." Halime

"It's hard to keep students focused." Aydan

"Students want to talk at the same time during distance education." Halime

"Students want to talk at the same time, which makes education more difficult than it already is." Buket

"Students do not want to do the activities." Zehra

"They are young kids, so, they don't want to do activities online." Ayça

"Distance education is not appropriate for students' levels." Medine

"Preschool teachers do not know much about distance education, which makes it all the more difficult." Gözde

"I've realized that I don't know much about web-based activities." Ali 


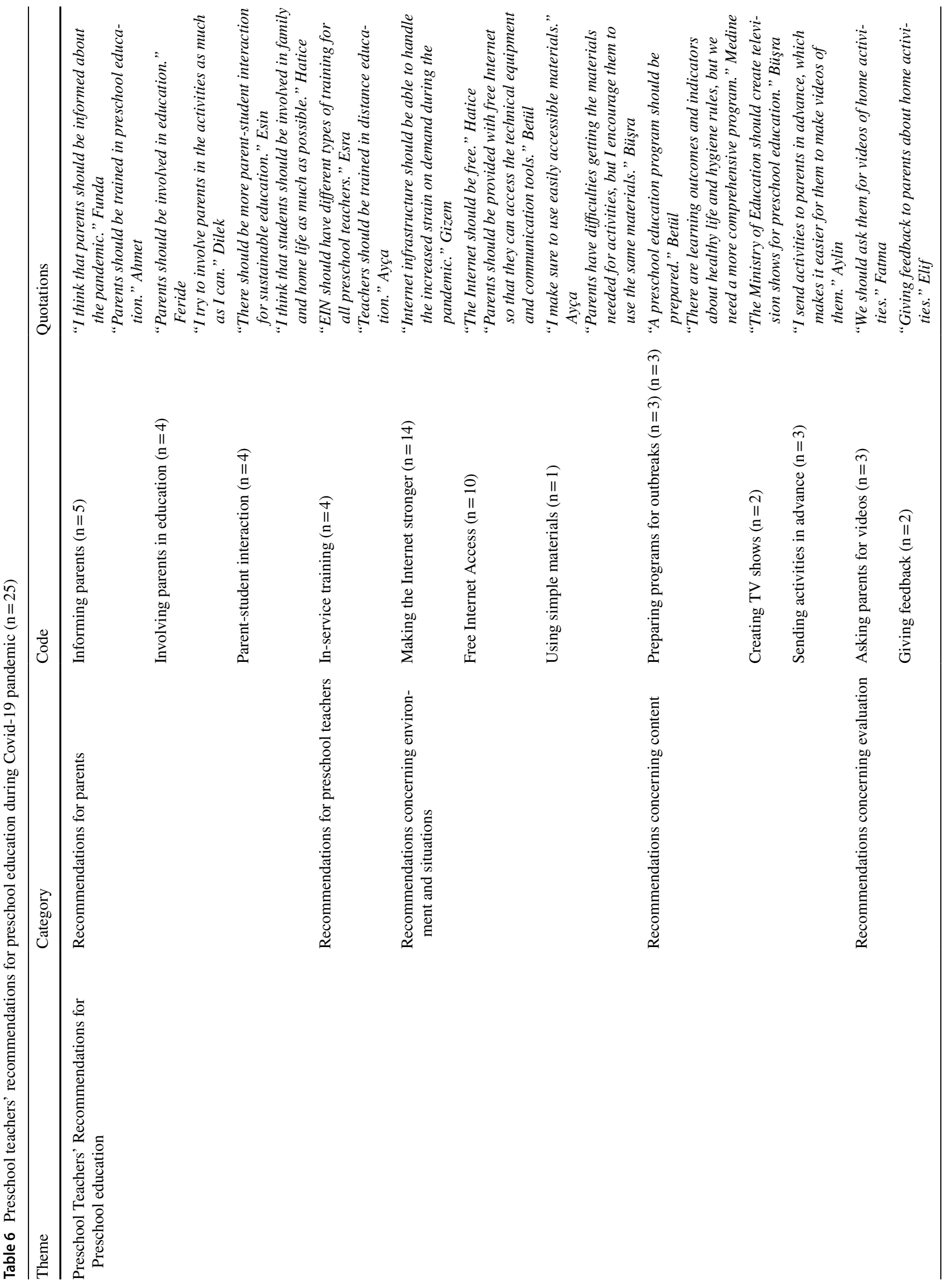


Table 7 Measures for sustainable preschool education during outbreaks $(n=25)$

\begin{tabular}{|c|c|c|c|}
\hline Theme & Category & Code & Quotations \\
\hline \multirow[t]{10}{*}{ Measures } & \multirow[t]{8}{*}{ Environment and source } & Making activity videos $(n=20)$ & $\begin{array}{l}\text { "There should be activity videos on preschool edu- } \\
\text { cation." Gizem } \\
\text { "There should be activity videos to make home } \\
\text { education easier for parents." Gözde }\end{array}$ \\
\hline & & Free Internet access $(n=18)$ & "Free Internet access should be provided." Hatice \\
\hline & & $\begin{array}{l}\text { Starting a TV channel for preschool education } \\
\quad(\mathrm{n}=18)\end{array}$ & $\begin{array}{l}\text { "There should be a TV channel for preschool educa- } \\
\text { tion." Buket } \\
\text { "There should be a play-based or experiment-based } \\
\text { EIN TV channel for preschool education." Ahmet }\end{array}$ \\
\hline & & Creating preschool activity sets $(\mathrm{n}=3)$ & $\begin{array}{l}\text { "Preschool education materials should be designed } \\
\text { for students." Büşra }\end{array}$ \\
\hline & & Preparing a parent guidebook $(\mathrm{n}=7)$ & $\begin{array}{l}\text { "There should be guidebooks on activities for } \\
\text { parents.” Dilek }\end{array}$ \\
\hline & & Revising the program $(n=6)$ & $\begin{array}{l}\text { "Preschool education programs should be revised } \\
\text { according to the pandemic." Fatma } \\
\text { "Every teacher gives home assignments off their } \\
\text { own bat, but I think there should be some sort of } \\
\text { plan and coordination". Halime }\end{array}$ \\
\hline & & Revising education policies $(\mathrm{n}=1)$ & “Education policies should be revised." Ali \\
\hline & & Preparing a preschool teacher guidebook $(\mathrm{n}=1)$ & $\begin{array}{l}\text { "There should be guidebooks for preschool teach- } \\
\text { ers." Gözde }\end{array}$ \\
\hline & \multirow[t]{2}{*}{ Preschool teacher training } & Organizing in-service training $(\mathrm{n}=15)$ & $\begin{array}{l}\text { "Preschool teachers should be trained on the pan- } \\
\text { demic." Medine } \\
\text { "Teachers should be trained in the use of technology } \\
\text { to avoid possible problems." Gizem }\end{array}$ \\
\hline & & $\begin{array}{l}\text { Adding courses to education faculty curricula } \\
(\mathrm{n}=1)\end{array}$ & $\begin{array}{l}\text { "I think that the sooner the preschool teachers are } \\
\text { informed about the pandemic, the better, and so, } \\
\text { there should be some courses about pandemics } \\
\text { offered by the faculties of education." Ali }\end{array}$ \\
\hline
\end{tabular}

\section{Parents' Recommendations for Preschool Education During the Covid-19 Pandemic}

The fourth research question of the second subproblem addressed parents' recommendations for preschool education during the Covid-19 pandemic.

\section{Parents' Responsibilities During Covid-19 Pandemic}

The fifth research question of the second subproblem addressed parents' responsibilities for preschool education during the Covid-19 pandemic.

Parents stated that they had to take on many responsibilities during the Covid-19 pandemic, such as doing activities together with their children and communicating with them effectively (Table 12).

\section{Measures for Sustainable Preschool Education During Outbreaks}

The sixth research question of the second subproblem addressed parents' views of measures that should be taken for sustainable preschool education during outbreaks.

Some of the measures that parents think should be taken for sustainable preschool education during outbreaks were starting a TV channel tailored to preschool education, creating web-based content available, and providing Internet access to all (Table 13).

\section{Activity Videos}

The third subproblem addressed activity videos sent by preschool teachers and parents.

The activity videos sent by preschool teachers and parents were grouped under two themes, two categories, seven subcategories, and 38 codes (Table 14). 
Table 8 Preschool teachers' views of the effects of Covid-19 pandemic on preschool education $(n=30)$

\begin{tabular}{lll}
\hline Theme & Category & Code \\
\hline $\begin{array}{c}\text { Effects of Covid-19 Pandemic on pre- } \\
\text { school education }\end{array}$ & Negative & Social development $(n=16)$
\end{tabular}

School adaptation $(\mathrm{n}=10)$

Student-student interaction $(\mathrm{n}=10)$

Preparation for primary school $(n=9)$

Teaching basic concepts $(n=6)$

Emotional development $(n=6)$

Preschool teacher-student interaction $(\mathrm{n}=5)$

Core skills $(n=4)$

Face to face education $(n=2)$

Academic performance $(n=1)$

Positive Parent-student interaction $(\mathrm{n}=1)$
Quotations

"The pandemic has impacted social development." Halil

"My kid is sorry that he's departed from his friends."

"Students were just getting used to school, but I feel like we are back to square one with the closure and all." Filiz

"My kid was growing a liking to school and getting used to it, but the pandemic's put a halt to that." Selver

"My daughter was upset that she had to part from friends." Gül

"My kid loved going to school and spending time with his classmates, but the pandemic has changed that." Naz.

"Preschool education is critical for primary school preparation, but I think pandemic has affected that process profoundly." Gülsüm

"The most important aspect of preschool education is that kids get to learn basic concepts, but the pandemic has put a halt to that." Nalan

"My kid missed the chance of learning things she was supposed to learn, but she's going to need those things in the future." Eda

"I think that pandemic affects children's mental health a lot." Nurhan

"She is sorry that she's been away from school and friends." Sude

"My son misses his preschool teacher." Demet

"It was upsetting for my daughter to be separated from her teacher. We call her all the time." Bilgin

"I think that the pandemic has prevented kids from learning the skills they were supposed to learn." Emine

"My kid was supposed to develop different skills during this period, but she can't do that now." Nil

"Kids need to learn face to face, but the pandemic wouldn't allow that to happen." Sude

"Preschoolers learn things together with their teachers. It's hard for them to learn online." Bilge

"The pandemic has a negative impact on academic performance." Beyza

"One perk of the pandemic is that we get to have fun together." Nazll

\section{Discussion}

According to preschool teachers, the Covid-19 pandemic has had an adverse impact on teaching basic concepts, emotional and mental development, teacher-student interaction, face-to-face education, preparation for primary school, and learning by doing. However, some think that the Covid-19 pandemic has improved parental engagement and 
Table 9 Home preschool education activities during Covid-19 pandemic $(\mathrm{n}=30)$

\begin{tabular}{|c|c|c|c|}
\hline Theme & Subtheme & Category & Code \\
\hline \multirow[t]{14}{*}{ Home preschool education activities } & $\begin{array}{l}\text { Doing activities sent by preschool teach- } \\
\text { ers }(n=16)\end{array}$ & - & $\begin{array}{l}\text { Doing activities only sent by preschool } \\
\text { teachers }(n=16)\end{array}$ \\
\hline & \multirow{13}{*}{$\begin{array}{l}\text { Doing both supportive activities and those } \\
\text { sent by preschool teachers }(n=14)\end{array}$} & Artistic activities & Cutting $(n=2)$ \\
\hline & & & Coloring $(n=8)$ \\
\hline & & \multirow[t]{2}{*}{ Turkish activities } & Reading books $(\mathrm{n}=3)$ \\
\hline & & & Reading stories () \\
\hline & & \multirow[t]{3}{*}{ Science activities } & Experiment $(n=3)$ \\
\hline & & & Using simple tools $(n=3)$ \\
\hline & & & Preparing food in the kitchen $(n=1)$ \\
\hline & & \multirow[t]{3}{*}{ Music activities } & Singing $(n=2)$ \\
\hline & & & Moving to music $(n=1)$ \\
\hline & & & Making creative moves and dancing $(n=1)$ \\
\hline & & \multirow[t]{2}{*}{ Math activities } & Counting $(n=3)$ \\
\hline & & & Matching $(\mathrm{n}=1)$ \\
\hline & & Games & Pair games $(n=7)$ \\
\hline
\end{tabular}

student-parent interaction. Preschool education is the period when children develop cognitive, affective, and psychomotor skills and learn basic concepts (Aslanargun and Tapan 2011; Senemoğlu 1994). Therefore, it can be concluded that the Covid-19 pandemic has adverse implications for preschool education.

Preschool teachers have provided distance education, designed activities, and given feedback about them, in order to maintain preschool education during the Covid-19 pandemic. They have also sent activity videos, communicated with parents, and recommended books. Preschoolers should develop basic skills and learn core concepts at home during the Covid-19 pandemic because those who fail to do so are more likely to have difficulty learning them at a later age (Kesicioglu and Alisinanoglu 2009). Epstein (1995) argues that a home environment that promotes learning helps children develop cognitive, affective, social, and academic skills. Therefore, we can conclude that activities carried out by teachers are of paramount importance for preschoolers' development.

Preschool teachers have engaged their students in performing art, Turkish, science, drama, music, and math activities and games during the Covid-19 pandemic, as recommended for multidirectional development (Eurydice 2010; Çınar 2013; Ulutaş Avcu 2015). Therefore, we can conclude that activities provided by preschool teachers can help children develop different skills, despite the adverse effects of the pandemic.

Preschool teachers help their students develop collaboration, problem-solving, communication, critical thinking, responsibility, flexibility, and adaptability skills, as well as technology literacy, awareness, self-confidence, and handeye coordination. They indicated that they would also like to teach their students about health, hygiene, numbers, shapes, and patterns, which are among the target skills and concepts of preschool education (Dodge et al. 2002; Ulusoy 2003; Uyanık and Kandır 2010).

Preschool teachers contact parents and students on the phone, WhatsApp, Video call, Facebook, and Instagram. Research also shows that preschool teacher-parent communication is critical for sustainable preschool education (Aktaş Arnas 2017; Gökçe 2000; Wherry 2009).

During the pandemic, preschool teachers have to deal with inaccessible or noisy students with short attention spans, Internet connection issues, financial difficulties, and reluctant and inaccessible parents who intervene in education and give no feedback. Research also shows that parental involvement improves preschool education (Abbak 2008; Cömert and Güleç 2004). The parental, situational, and student-related problems have been reported by earlier studies as well (Andsoy et al. 2012; Çı̆̆lık and Bayrak 2015). Preschool teachers also stated that they did not know much about distance education, which is a problem that should be addressed through in-service training (Odabas 2003). They recommend parental training and involvement in education. They also suggest that students be provided with free and high-speed Internet access and activities in advance.

Some of the recommendations made by preschool teachers for sustainable preschool education during outbreaks include providing families with free Internet access, starting a TV channel, preparing distance education programs and guidebooks for parents and teachers, organizing in-service training, and offering more courses in education faculties.

Almost all parents think that the Covid-19 pandemic has adverse effects on socialization, preparation for primary 
Table 10 Challenges of preschool education for parents during Covid-19 pandemic $(n=30)$

\begin{tabular}{|c|c|c|c|}
\hline Theme & Category & Code & Quotations \\
\hline \multirow[t]{10}{*}{$\begin{array}{l}\text { Challenges of preschool education } \\
\text { for parents }\end{array}$} & \multirow[t]{2}{*}{$\begin{array}{l}\text { Of environment and situation } \\
\text { origin }\end{array}$} & Lack of materials $(n=7)$ & $\begin{array}{l}\text { “We don't have as much material at } \\
\text { home as we do in school.” Naz } \\
\text { "Activity materials are not avail- } \\
\text { able, and besides, we sometimes } \\
\text { cannot go out to get them." Akine }\end{array}$ \\
\hline & & Financial difficulties $(\mathrm{n}=2)$ & $\begin{array}{l}\text { “We need money to buy stuff for } \\
\text { activities.” Esin } \\
\text { "We need to buy some materials to } \\
\text { perform the activities the teacher } \\
\text { asks us to, but we need money } \\
\text { to buy them, which is sometimes } \\
\text { hard." Dilek }\end{array}$ \\
\hline & \multirow[t]{3}{*}{ Of parent origin } & Low self-confidence $(n=2)$ & $\begin{array}{l}\text { "I feel incompetent in such things." } \\
\text { Esma }\end{array}$ \\
\hline & & Communication problems $(\mathrm{n}=2)$ & $\begin{array}{l}\text { "I have a hard time communicating } \\
\text { with my kid." Aylin } \\
\text { "My kid just wouldn't listen to me } \\
\text { and wouldn't do his homework." } \\
\text { Halil }\end{array}$ \\
\hline & & Household chores $(n=1)$ & $\begin{array}{l}\text { "Another thing is that we have to } \\
\text { do household chores every day." } \\
\text { Dilek }\end{array}$ \\
\hline & \multirow[t]{4}{*}{ Of student origin } & $\begin{array}{l}\text { Not finishing home assignments } \\
\quad(\mathrm{n}=13)\end{array}$ & $\begin{array}{l}\text { “My kid leaves an activity halfway } \\
\text { finished when he doesn't want to } \\
\text { do it." Akine } \\
\text { "My kid doesn't do his homework } \\
\text { as regularly as he did at school." } \\
\text { Filiz. }\end{array}$ \\
\hline & & Lack of concentration $(n=9)$ & $\begin{array}{l}\text { "My kid has a hard time concen- } \\
\text { trating on activities." Bilge } \\
\text { "My kid can't concentrate, so we } \\
\text { have a hard time doing the activi- } \\
\text { ties." Gül }\end{array}$ \\
\hline & & Lack of interest $(n=4)$ & $\begin{array}{l}\text { "My kid is not interested in the } \\
\text { activities." Nil } \\
\text { "My kid is very discouraged } \\
\text { because he doesn't go to school, } \\
\text { which is upsetting to both of us." }\end{array}$ \\
\hline & & Reduced motivation $(\mathrm{n}=1)$ & $\begin{array}{l}\text { "My kid is not as focused when } \\
\text { she is home as she would be in } \\
\text { school." Bilgin }\end{array}$ \\
\hline & Of preschool teacher origin & $\begin{array}{l}\text { An excessive amount of home- } \\
\text { work }(\mathrm{n}=3)\end{array}$ & $\begin{array}{l}\text { "Preschool teachers assign too } \\
\text { much homework, but the kids are } \\
\text { already going through a tough } \\
\text { time." Sude }\end{array}$ \\
\hline
\end{tabular}

school, emotional development, teacher-student interaction, face-to-face education, and academic performance. Only one parent believes that the Covid-19 pandemic has improved parent-student interaction, which is an essential part of preschool education (Castro et al. 2015; Erdoğan and Demirkasımoğlu 2010). Parents and preschool teachers agree that the Covid-19 pandemic has had a debilitating impact on education in general.

Most parents use only the activities sent by preschool teachers, while others undertake art, Turkish, science, music and math activities in addition to the ones sent by preschool teachers. Parental involvement in education makes school programs more effective and students' learning more possible (Aslanargun 2007; Lawson 2003; Epstein 1995). Our results also show that parents and preschool teachers work together to perform activities to improve students' learning.

For parents, the challenges of preschool education during the pandemic include a lack of resources, economic problems (situational), low self-confidence, communication problems, household chores (personal), concentration 
Table 11 Parents' recommendations for preschool education during Covid-19 pandemic $(n=30)$

\begin{tabular}{|c|c|c|c|}
\hline Theme & Category & Code & Quotations \\
\hline \multirow[t]{8}{*}{$\begin{array}{l}\text { Parents' recommendations for } \\
\text { preschool education }\end{array}$} & \multirow[t]{3}{*}{ Recommendations to students } & Making activities more fun $(n=6)$ & $\begin{array}{l}\text { "We make the activities more fun." } \\
\text { Eda } \\
\text { "I play games with my kid to get her } \\
\text { to do activities.” Halil }\end{array}$ \\
\hline & & $\begin{array}{l}\text { Getting students to talk to their } \\
\text { friends }(n=2)\end{array}$ & $\begin{array}{l}\text { "I get my kid to talk to her school- } \\
\text { mates when she misses them." } \\
\text { Mehtap }\end{array}$ \\
\hline & & Rewarding $(\mathrm{n}=1)$ & $\begin{array}{l}\text { "I let my kid watch TV or play on the } \\
\text { phone as a reward." Dilek }\end{array}$ \\
\hline & \multirow[t]{3}{*}{$\begin{array}{l}\text { Recommendations concern- } \\
\text { ing the teaching-learning } \\
\text { process }\end{array}$} & Using different materials $(n=5)$ & $\begin{array}{l}\text { “We use alternative materials for } \\
\text { activities.” Selver } \\
\text { "I come up with activities when I } \\
\text { don't have the materials for the } \\
\text { activities that the teacher sends } \\
\text { us." Esin }\end{array}$ \\
\hline & & Supplying materials $(n=3)$ & "We try to supply materials." Gül \\
\hline & & Turning the TV off $(n=2)$ & $\begin{array}{l}\text { "We turn off the TV to keep our kid } \\
\text { focused." Filiz }\end{array}$ \\
\hline & \multirow[t]{2}{*}{ Recommendations to parents } & $\begin{array}{l}\text { Receiving support from preschool } \\
\text { teachers }(n=7)\end{array}$ & $\begin{array}{l}\text { "We ask my kid's preschool teacher } \\
\text { for help when we have a problem." } \\
\text { Gülsüm }\end{array}$ \\
\hline & & Effective communication $(\mathrm{n}=3)$ & $\begin{array}{l}\text { "I try to communicate effectively with } \\
\text { my kid." Nalan }\end{array}$ \\
\hline
\end{tabular}

Table 12 Parents' responsibilities during Covid-19 pandemic $(\mathrm{n}=30)$

\begin{tabular}{|c|c|c|}
\hline Theme & Code & Quotations \\
\hline \multirow[t]{7}{*}{ Responsibilities } & Teaching $(\mathrm{n}=17)$ & $\begin{array}{l}\text { "Now we have to do everything that preschool teachers did in the class- } \\
\text { room." Nalan } \\
\text { "We have to be both a parent and a teacher at home." Selver }\end{array}$ \\
\hline & Doing activities together $(n=16)$ & $\begin{array}{l}\text { "I and my kid do the activities that his preschool teacher asks him to do." } \\
\text { Nurhan } \\
\text { "We spend more time together doing activities." Mehtap }\end{array}$ \\
\hline & Devoting attention $(n=12)$ & $\begin{array}{l}\text { "I've realized that I have to spend more time with my son and devote more } \\
\text { attention to him to make sure that he's not alienated from school." Gülhan } \\
\text { "I talk to my son and do activities with him to make sure that he doesn't get } \\
\text { bored." Eda }\end{array}$ \\
\hline & Getting them to do homework $(\mathrm{n}=10)$ & $\begin{array}{l}\text { "Getting our homework done." Demet } \\
\text { "We get our kid to do the activities that the teacher sends us." Sude }\end{array}$ \\
\hline & Communicating with preschool teachers $(n=6)$ & $\begin{array}{l}\text { "We cooperate with the preschool teacher and support our kid's education." } \\
\text { Emine } \\
\text { "I call my kid's teacher, and she video calls us or texts us on WhatsApp and } \\
\text { helps us with activities." Bilgin }\end{array}$ \\
\hline & Learning core concepts $(n=4)$ & $\begin{array}{l}\text { "We try to teach our kids the basic concepts that they were supposed to learn } \\
\text { in school." Beyza }\end{array}$ \\
\hline & Helping to develop core skills $(\mathrm{n}=2)$ & $\begin{array}{l}\text { "We make sure that the kids do not forget the skills they learned in school and } \\
\text { support their social development." Suden }\end{array}$ \\
\hline
\end{tabular}

problems, laziness, disinterest, and reduced motivation on the part of their children, which has been reported by earlier studies as well (Hornby and Lafaele 2011; Nakamura 2000). Parent-student communication problems impede education (Wherry 2009). Günay Bilaloğlu and Aktaş Arnas (2019) argue that parents are reluctant to get involved in their children's education because they have little self-confidence and knowledge and have to keep up with household chores. However, our results beg to differ because they suggest that parents need encouragement to be involved in their children's education (Aktaş Arnas 2017). 
Table 13 Measures for sustainable preschool education during outbreaks $(n=30)$

\begin{tabular}{|c|c|c|}
\hline Theme & Code & Quotations \\
\hline \multirow[t]{6}{*}{ Measures } & Starting a TV channel for preschool education $(n=6)$ & "There should have been a TV channel for preschool education." Nazll \\
\hline & Creating web-based content $(n=5)$ & "There should be online content available." Naz \\
\hline & Designing simple activities $(n=3)$ & "Fun and simple home activities should be developed." Filiz. \\
\hline & Improving preschool teacher-student interaction $(n=2)$ & $\begin{array}{l}\text { "Preschool teachers should video call more often because the kids miss } \\
\text { them." Aydan } \\
\text { "All we need is the teacher's support during this period, so we should be in } \\
\text { touch with her." Gül }\end{array}$ \\
\hline & Preparing a parent guidebook $(\mathrm{n}=2)$ & $\begin{array}{l}\text { "I need guidebooks with more detailed information about the activities." } \\
\text { Aylin } \\
\text { "We don't know as much as the teachers, and so, there should be some } \\
\text { books we can learn from." Gülsüm }\end{array}$ \\
\hline & Free Internet access $(n=2)$ & $\begin{array}{l}\text { "Not everyone has the Internet at home, so I can't check on the educational } \\
\text { content, everyone should have access to the Internet." Sude } \\
\text { "Everyone should have free Internet access." Nurhan }\end{array}$ \\
\hline
\end{tabular}

Effective teacher-parent communication helps the latter undertake educational activities at home (Aktas Arnas 2017; Günay Bilaloğlu and Aktaş Arnas 2019). Some recommendations made by parents for a more effective preschool education during the Covid-19 pandemic are using more engaging activities, getting students to talk to their schoolmates, rewarding them, using different types of materials, and turning the TV off. They also suggest that teachers support parents and communicate with them effectively.

Parents believe that they are responsible for teaching their children basic concepts, helping them to develop skills, participating in activities, devoting attention to them, getting them to do their homework, and communicating with their teachers. Both parents and preschool teachers believe that authorities should start a TV channel, create web-based content, design simple activities, improve teacher-student interaction, prepare a parent guide, and provide Free Internet access for sustainable preschool education during outbreaks.

The videos from preschool teachers show that they face numerous problems during distance education and try hard to involve their students in activities. The videos from parents show that they also face problems during distance education, assume various responsibilities, and undertake activities in addition to those sent by preschool teachers. However, the results also show that preschool teachers and parents do not face the same problems and do not work together to solve them, despite the significance of parent-teacher cooperation for sustainable preschool education (Aktaş Arnas 2017; Günay Bilaloğlu and Aktaş Arnas 2019; Wherry 2009).

\section{Conclusion and Recommendations}

All participants believed that the Covid-19 pandemic has adversely affected students' cognitive, affective, and psychomotor skills. Therefore, preschool education should be sustained to help children complete their development. Preschool teachers and parents should be informed of outbreaks. Explanatory guidebooks should be available for training. Authorities should start TV channels and design Web-based preschool education programs with activity videos and guidebooks for sustainable preschool education during outbreaks. However, TV channels or activities are not enough to train preschoolers about outbreaks. We need alternative methods because although parents are primarily responsible for providing education during outbreaks, they may not be qualified or may not have enough time to do it. Moreover, families with more than one child who receives distance education should be provided with technological devices (e.g., tablet, computer, etc.) and free Internet access. What is more, some preschoolers may have attention and concentration difficulties and may need face-to-face learning by playing. Therefore, distance education should include as many TV-compatible games and activities as possible. Another point is that preschool activities should be as short as possible because it is hard for children to stay focused on a computer screen for a long time.

During the Covid-19 pandemic, preschool teachers and parents have worked together to provide distance education and undertake art, Turkish, science, music, and mathematics to help preschoolers develop collaboration, problem-solving, communication, and critical thinking skills. Therefore, both preschool teachers and parents should be provided with web-based content so that they can help preschoolers develop cognitive, affective, and psychomotor skills during 
Table 14 Characteristics of activity videos

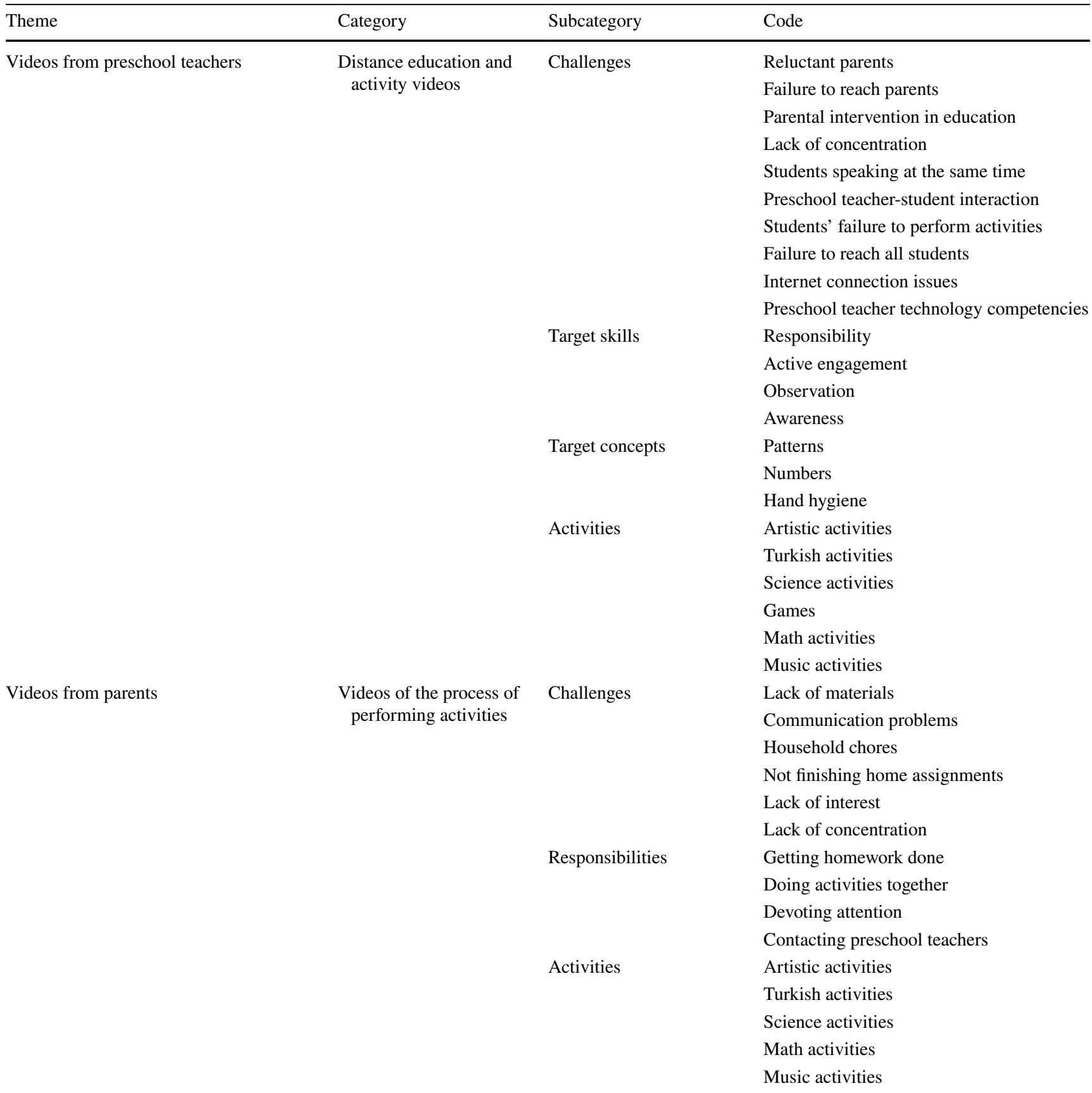

outbreaks. The content should consist of educational activities, materials, and games available to all.

Preschool teachers and parents face numerous problems and find different solutions to them during the Covid-19 pandemic. Authorities should take those problems and solutions into account to devise plans to sustain distance education during outbreaks. Preschool teachers and parents suggest that families should be provided with free and high-speed Internet access, guidebooks, and training in sustainable distance education during outbreaks. Preschool teachers should be trained in technology-based education as well as technological pedagogical content knowledge, so that they can be of help to their students during outbreaks.

We believe that this study will provide a basis for all stakeholders of distance education. Policymakers should formulate plans for sustainable preschool education and make sure that all interested parties implement it effectively during outbreaks. Moreover, education programs should contain more information about outbreaks and involve parents in the process. We believe that this study will pave the way for 
further research on the effects of the Covid-19 pandemic on other grade levels and the challenges teachers face.

\section{Limitations}

This study had three limitations. Although education during the Covid-19 pandemic varies from country to country, this study investigated the effects of the Covid-19 pandemic on preschool education only in Turkey, and therefore, the results cannot be generalized, which is the first limitation. Second, the sample consisted only of preschool teachers and parents in Turkey. Third, the assessment was based on self-report.

Acknowledgments or Notes The author would like to acknowledge and thank the teachers for their participation in the research.

\section{Appendix 1: Preschool Teachers Interview Form (PTIF)}

1. Why Preschool teacher Interview Form (Cov19TIF)

2. What effects do you think the Covid-19 pandemic has on preschool education?

3. What do you do to provide sustainable preschool education during the Covid-19 pandemic?

4. What activities do you get your students to perform during the Covid-19 pandemic?

5. What are the target skills and concepts of the activities that you get your students to perform during the Covid19 pandemic?

6. How do you communicate with your students during the Covid-19 pandemic?

7. What are the challenges of preschool education during the Covid-19 pandemic, and what are your solutions to them?

8. What measures do you think should be taken for sustainable preschool education during the Covid-19 pandemic?

\section{Parent Interview Form (Cov19PIF)}

1. What effects do you think the Covid-19 pandemic has on preschool education?

2. What activities do you get your children to perform at home during the Covid-19 pandemic?

3. What problems do you face when you get your children to perform activities at home during the Covid-19 pandemic?
4. What are your solutions to the problems that you face when you get your children to perform activities at home during the Covid-19 pandemic?

5. What responsibilities do you think you have for your children's preschool education during the Covid-19 pandemic?

6. What measures do you think should be taken for sustainable preschool education during the Covid-19 pandemic?

\section{References}

Abbak, B. S. (2008). The survey of the family involvement activities in preschool training programme in terms of preschool teachers and parental view. Adana: Çukurova University (Unpublished master thesis).

Aktaş Arnas, Y. (2017). Aile eğitimi ve okul öncesinde aile katılımı. Ankara: Vize Yayıncılık.

Andsoy, I. I., Güngör, T., Bayburtluoğlu, T., \& Yaman, S. (2012). Karabük university school of health first class of nursing students' thoughts on the system of distance education. Türkiye Klinikleri Hemşirelik Bilimleri Dergisi, 4(2), 66-73.

Aslanargun, E. (2007). The review of literature on school-parent cooperation and students' school success. Manas Üniversitesi Sosyal Bilimler Dergisi, 9(18), 119-135 Retrieved from https://dergipark. org.tr/tr/pub/manassosyal/issue/49947/640068.

Aslanargun, E., \& Tapan, F. (2011). Preschool education and its effects on children. Abant İzet Baysal Üniversity, Education Faculty Journal, 11(2), 219-238 Retrieved from https://dergi park.org.tr/tr/pub/aibuefd/issue/1509/18305.

Burgess, S. \& Sievertsen, H.H. (2020). Schools, skills, and learning: The impact of COVID-19 on education. Retrieved from https:// voxeu.org/article/impact-covid-19-education

Castro, M., Exposito-Casas, E., Lopez-Martin, E., Lizasoain, L., Navarro-Asencio, E., \& Gaviria, J. L. (2015). Parental involvement on student academic achievement: A meta-analysis. $E d u$ cational Research Review, 14, 33-46. https://doi.org/10.1016/j. edurev.2015.01.002.

Çı̆̆lık, H., \& Bayrak, M. (2015). Distance learning and constructivist approach. Istanbul Journal of Open and Distance Education (IJODE), 1(1), 87-102.

Çınar, S. (2013). Determining the activities used by pre-school teachers in science and nature uses. Journal of Research in Education and Teaching, 2(1), 364-371.

Cömert, D., \& Güleç, H. (2004). The significance of family participation in the pre-school institutions: Teacher- family-child and institution. Afyon Kocatepe Üniversitesi Sosyal Bilimler Dergisi, 6(1), 131-145.

Creswell, J. W. (2007). Qualitative inquiry and research design: Choosing among five approaches (2nd ed.). Thousands Oaks: Sage Publications, Inc..

Davies, S. E. (2013). National security and pandemics. UN Chronicle, 50(2), 20-24.

Dodge, D. T., Colker, L. J., \& Heroman, C. (2002). The creative curriculum for preschool. Washington, DC: Teaching Strategies, Inc..

Eğitim Bilişim A $\breve{g}$ [EBA]. (2020). EBA TV lesson broadcast. Retrieved from http://www.eba.gov.tr/

Epstein, J. L. (1995). School/family/community partnerships: Caring for the children we share. Phi Delta Kappan, 76(9), 81-96. 
Erdoğan, Ç., \& Demirkasımoğlu, N. (2010). Teachers' and school administrators' views of parent involvement in education process. Educational Administration: Theory and Practice, 16(3), 399-431.

Eurydice. (2010). Avrupa'da ĕgitim ve öğretim sistemlerinin yapısı [The structure of education and training systems in Europe]. Türkiye: European Commission Eurodice.

Gökçe, E. (2000). Improve the cooperation of school-family in elementary education. Pamukkale Üniversitesi Eğitim Fakültesi Dergisi, 7(7), 204-209.

Gostin, L. O., \& Friedman, E. A. (2015). A retrospective and prospective analysis of the west African Ebola virus disease epidemic: Robust national health systems at the foundation and an empowered WHO at the apex. The Lancet, 385(9980), 1902-1909. https ://doi.org/10.1016/S0140-6736(15)60644-4.

Günay Bilaloğlu, R., \& Aktaş Arnas, Y. (2019). Barriers to parental involvement in preschool education and problems encountered in process. Hacettepe University Journal of Education, 34(3), 804-823. https://doi.org/10.16986/HUJE.2018043536.

Hornby, G., \& Lafaele, R. (2011). Barriers to parental involvement in education: An explanatory model. Educational Review, 63(1), 37-52. https://doi.org/10.1080/00131911.2010.488049.

Karp, P., \& McGowan, M. (2020). Clear as mud': Schools ask for online learning help as coronavirus policy confusion persists. The Guardian, 261-307.

Kawano, S., \& Kakehashi, M. (2015). Substantial impact of school closure on the transmission dynamics during the pandemic flu h1n1-2009 in Oita, Japan. PLoS One, 10(12), 1-15. https://doi. org/10.1371/journal.pone.0144839.

Kesicioglu, O. K., \& Alisinanoglu, F. (2009). 60-72 months childs' attitudes toward environment in terms of some variables. Journal of Ahi Evran University Faculty of Education, 10(3), 37-48.

Lawson, M. A. (2003). School-family relations in context: Parent and teacher perceptions of parent involvement. Urban Education, 38 , 77-133. https://doi.org/10.1177/0042085902238687.

Massachusetts Office of the Child Advocate. (2020). Commonwealth of Massachusetts office of the child advocate. Retrieved from https ://www.mass.gov/doc/cttf-june-2020-report-protecting-our-child rens-well-being-during-covid-19-0/download

Miles, M. B., \& Huberman, A. M. (1994). Qualitative data analysis (2nd ed.). Thousand Oaks, CA: Sage.

Nabarro, D., \& Wannous, C. (2016). The links between public and ecosystem health in light of the recent ebola outbreaks and pandemic emergence. EcoHealth, 13(1), 227-229. https://doi.org/10.1007/ s10393-016-1123-y.

Nakamura, R. M. (2000). Healthy classroom management: Motivation, communication, and discipline. Canada: Wadsworth Thomson Pub.

Odabaş, H. (2003). Internet based distance education and departments of information and records management. Türk Kütüphaneciliği, $17(1), 22-36$.
Patton, M. (2002). Qualitative evaluation and research methods. Beverly Hills, CA: Sage.

Pramling Samuelsson, I., Wagner, J. T., \& Eriksen Ødegaard, E. (2020). The Coronavirus pandemic and lessons learned in preschools in Norway, Sweden and The United States: OMEP policy forum. International Journal of Early Childhood, 52, 129-144. https://doi.org/10.1007/s13158-020-00267-3.

Senemoğlu, N. (1994). Okulöncesi eğitim programı hangi yeterlikleri kazandırmalıdır? Hacettepe Üniversitesi Eğitim Fakültesi Dergisi, $10,21-30$.

Turan, F. (2004). Regulation on pre-school education institutions and programme evaluation. Milli Ĕgitim ve Sosyal Bilimler Dergisi, $25,162$.

Ulusoy, A. (2003). Öğrenme. In A. Ulusoy (Ed.), Gelişim ve öğrenme (pp. 137-148). Ankara: Anı Yayıncılık.

Ulutaş Avcu, A. (2015). Examination of the opinions of preschool teachers regarding game activities. Journal of International Social Research, 8(41), 1052-1058.

UNESCO, (2020). 90 million students out of school due to COVID-19: UNESCO releases first global numbers and mobilizes response. Retrieved from https://en.unesco.org/news/290-million-studentsout-school-due-covid-19-unesco-releases-first-global-numbersand-mobilizes

Uyanık, Ö., \& Kandır, A. (2010). Early academic skills in preschool period. Kuramsal Ĕ̆itimbilim, 3(2), 118-134 Retrieved from https ://dergipark.org.tr/tr/pub/akukeg/issue/29341/313983.

Verikios, G., Sullivan, M., Stojanovski, P., Giesecke, J., \& Woo, G. (2015). Assessing regional risks from pandemic influenza: A scenario analysis. The World Economy, 39(8), 1225-1255. https://doi. org/10.1111/twec. 12296.

Viner, R. M., Russell, S. J., Croker, H., Packer, J., Ward, J., Stansfield, C., Mytton, O., Bonell, C., \& Booy, R. (2020). School closure and management practices during coronavirus outbreaks including COVID-19: A rapid systematic review. The Lancet Child \& Adolescent Health, 4(5), 397-404. https://doi.org/10.1016/S2352 $-4642(20) 30095-X$.

Wherry J.H. (2009). Shattering barriers to parent involvement. Retrieved from https://www.naesp.org/sites/default/files/resou rces/2/Principal/2009/M-J_p07.pdf

Yıldırım, A., \& Şimşek, H. (2011). Sosyal bilimlerde nitel araştırma yöntemleri [Qualitative research methods in the social sciences]. İstanbul: Seçkin Yayınları.

Publisher's Note Springer Nature remains neutral with regard to jurisdictional claims in published maps and institutional affiliations. 